\title{
Screening of Microsatellite Markers for Genetic Diversity Assessment and Conservation of Germplasm in Okra (Abelmoschus esculentus L. Moench)
}

\author{
Mukesh Kumar', V. Rakesh Sharma, Navneet Kumar², Ujjawal Sirohi ${ }^{3}$, \\ R.K. Naresh ${ }^{4}$ and Veena Chaudhary ${ }^{5}$ \\ ${ }^{1}$ Department of Horticulture, ${ }^{2}$ Department of Genetics and Plant Breeding, ${ }^{3}$ College of \\ Biotechnology, ${ }^{4}$ Department of Agronomy, Sardar Vallabhbhai Patel University of Agriculture \\ and Technology, Meerut-250 110, U.P., India \\ ${ }^{5}$ CSSS (PG) College, Machhra, Meerut-250106, UP, India \\ *Corresponding author
}

\section{A B S T R A C T}

Keywords

Okra,

Genetic diversity,

Single sequence

repeats,

Microsatellite markers.

Article Info

Accepted:

04 May 2017

Available Online:

10 June 2017
In the present investigation, an attempt has been made to evaluate the germplasm conservation of some polymorphism information and the genetic diversity in Sixty-nine germplasm of okra collected from the IIVR (59) and IIHR (10), India. Microsatellite marker indicated that a total of 24 distinct bands were found polymorphic with an average of 2.4 bands per primer. The polymorphism information content (PIC) values varied from 0.492 to 0.999 with an average 0.729 and resolving power (RP) varied 0.145 to 3.97 with an average 1.841 . Genetic similarity value among the okra germplasm varied from 0.50 to 0.95 with an average 0.772 . On the basis of Microsatellite marker, there could be a low level of variation among the germplasm. UPGMA analysis showed that three major groups among the germplasm and dendrogram exhibited that some of the genotypes showed similarity at the molecular level. The results obtained from the present study clearly demonstrate that the genotypes 212-10-1, 167, Kashi Pragati and 1999 were found more diverse and may be useful as promising cultivars in okra breeding programme.

\section{Introduction}

Okra (Abelmoschus esculentus L. Moench) is cultivated in tropical, subtropical, and warm temperate regions around the world. Okra production worldwide is estimated at six million tonnes per year. In West Africa, it is estimated at 500,000 to 600,000 tonnes per year (Burkil, 2002). The total area under cultivation has increased over the years. India is the largest producer of okra in world followed by Nigeria and Sudan (Varmudy,
2011). The whole body of the okra is a treasure. The leaves and seeds are considered a valuable traditional medicine (Gul et al., 2011). Okra seeds contain abundant mineral elements, including iron, potassium, calcium, and manganese. It is also an oil and protein source, which can be used as a coffee additive (i.e., in place of drinking coffee). The nutritional value of $100 \mathrm{~g}$ of edible okra is characterized $1.9 \mathrm{~g}$ protein, $0.2 \mathrm{~g}$ fat, $6.4 \mathrm{~g}$ 
carbohydrate, $0.7 \mathrm{~g}$ minerals and $1.2 \mathrm{~g}$ fibers. Okra fruit contains sufficient amounts of iron, calcium, manganese and magnesium, vitamins $\mathrm{A}, \mathrm{B}, \mathrm{C}$ and $\mathrm{K}$, as well as folates and very high levels of antioxidants such as xanthin and lutein (Kumar et al., 2010). Okra was considered a minor crop until more attention was paid to its recent genetic improvements (Schafleitner et al., 2013), especially its rapid growth cycle, easy cultivation, resistance to pests, high yield, and high nutritional value (Calisir et al., 2005).

Okra is an allopolyploid plant with considerable variation in its chromosome number and ploidy level. The chromosome number ranges from 56 for Abelmoschus angulosus to 200 for A. caillei, an amphipolyploid between A. esculentus and $A$. caillei (Ford, 1938) and (Siemonsma, 1982). In India, efforts of germplasm collection and evaluation have been made but the information for higher yield and yield contributions characters is limited. Therefore, it is more essential to estimate the genetic variation among the germplasm for selection of diverse parents which may be useful as donor for complementary various breeding programs. The diverse parents belonging to different distant clusters would provide an opportunity for bringing together gene constellations of diverse nature promising hybrid derivatives result probably due to complementary interaction of divergent in parent (Anand and Murthy, 1968).

Morphological characterization of plants is common step in plant breeding and this method can be influenced by environmental or physiological factors. Therefore, molecular markers developed for measuring genetic diversity in crop plants. Among several markers available, microsatellite or simple sequence repeat occur ubiquitously and abundantly in eukaryotic genomes. As molecular markers, they combine many desirable marker properties including highlevel polymorphism and information content, an unambiguous designation of alleles, even dispersal, selective neutrality, high reproducibility, co-dominance and rapid and simple genotyping assays.

The present study was carried out for the microsatellite molecular markers of choice for a wide range of application in genetic mapping and genome analysis.

\section{Materials and Methods}

\section{Experimental site}

The field experiment was conducted at Horticultural Research Centre of Sardar Vallabhbhai Patel University of Agriculture \&Technology, Meerut research farm (290 04', $\mathrm{N}$ latitude and 770 42' 'E longitude a height of $237 \mathrm{~m}$ above mean sea level) U.P., India. During the year of the field experiment, mean weekly maximum and minimum air temperature for the crop season was recorded ranged from 16.3 to $36.4^{\circ} \mathrm{C}$ and 5.2 to $19.6^{\circ} \mathrm{C}$, respectively. The area receives an average annual rainfall of $695 \mathrm{~mm}$ (constituting $44 \%$ of pan evaporation) of which about $80 \%$ is received during the monsoon period.

\section{Soil of the experimental site}

A composite soil sample was collected from the experimental field to study the contents of available $\mathrm{N}, \mathrm{P}$ and $\mathrm{K}, \mathrm{pH}$, electric conductivity, organic carbon content and some physical properties of the soil. The soil analysis revealed that the soil was sandy-loam with 55, 18, and $27 \%$ sand, silt, and clay, respectively, Typic Ustochrept; non-saline $\left(\right.$ EC $0.42 \mathrm{dS} \mathrm{m}^{-1}$ ) but mild alkaline in reaction (pH 7.98). The soil $(0-15 \mathrm{~cm}$ depth) initially had $4.1 \mathrm{~g} \mathrm{~kg}^{-1}$ of SOC and 16.4, 96, and 14.5 $\mathrm{kg} \mathrm{ha}^{-1}$ of available $\mathrm{P}, \mathrm{K}$, and $\mathrm{S}$, respectively. 


\section{Plant material}

A total of sixty-nine diverse okra genotypes collected from different parts of India were used for this study (Table 1). Seeds were raised in the prepared soil at open field for better growth. Young, healthy third to fourth leaf from the bottom of the okra genotypes were collected from the field in an aluminium foil and washed thoroughly with distilled water and air dried to remove moisture. 100 $110 \mathrm{mg}$ of leaf material was used to extract DNA for the present study.

\section{DNA extraction}

Okra is highly mucilage and its mucilage interferes in DNA isolation procedure as an impurity. In this present study, we have developed the protocol for highly purity DNA isolation from the fresh leaves of okra and PCR analysis for resultant DNA. Due to this reason modified $\mathrm{CTAB}$ method provides better DNA extraction suitable for further genomic analysis through molecular markers. A standard protocol of (Doyle and Doyle, 1990) was reviewed and modified for DNA extraction from Okra tissues. Modification involved increase the volume of DNA extracting buffer use of polyvinylpolypyrrolidone employed, yielded a high-quality DNA and it is also used as a fining to extract impurities. For isolation of genomic DNA, leaves samples $(0.3 \mathrm{~g}$ of frozen leaf) were taken and ground to fine powder with a chilled mortar and pestle using liquid nitrogen. A pinch of Polyvinylpolypyrrolidone (PVP) were added to this and transferred to $2.0 \mathrm{ml}$ of pre-warmed $\left(65^{\circ} \mathrm{C}\right)$ extraction buffer $(2 \%$ w/v CTAB, 1.4 $\mathrm{M} \mathrm{NaCl}, 20 \mathrm{mM}$ EDTA, 100mM Tris-HCl $(\mathrm{pH} 8), 2 \%(\mathrm{v} / \mathrm{v}) 2$-mercaptoethanol) in $1.5 \mathrm{ml}$ tube. The samples were mixed well by inverting the tubes several times. Samples were incubated for 1 hour in a water bath at $65^{\circ} \mathrm{C}$ (dried sample required overnight incubation). An equal volume of Chloroform: Isoamylalcohol (24:1) was added to the tube and mixed gently for 15-20 minutes. These tubes were centrifuged at $8,000 \mathrm{rpm}$ for 10 minutes. After centrifugation aqueous phase (supernatant) was transferred to a fresh $1.5 \mathrm{ml}$ tube and again extracted with chloroform: isoamyl alcohol. $5 \mu \mathrm{l}$ of $(10 \mathrm{mg} / \mathrm{ml})$ RNase was added and incubated for 30 minutes. Aqueous layer was transferred to the fresh $1.5 \mathrm{ml}$ tube and added $1.0 \mathrm{ml}$ of $5 \mathrm{M} \mathrm{NaCl}$ and mixed gently. Chilled isopropanol (0.6 volumes) was added to the tube. After 2-hours of incubation at $-20^{\circ} \mathrm{C}$, these tubes were centrifuged at $10,000 \mathrm{rpm}$ for 10 minutes. After centrifugation, supernatant was discarded and pellet was washed with 70 percent ethanol. Finally, the air-dried pellet was dissolved in $100 \mu 1$ of T10 E1 buffer.

\section{Microsatellite data analysis}

A total of 19 microsatellite primer pairs, (Schafleitner et al., 2013) were initially tested. Out of 19 primers, only 10 primers that showed consistently good amplification were used for final study with all 69 okra genotypes.

Data generated by using 10 microsatellites primers on 69 okra genotypes were scored in binary format and further analyzed as described previously (Kumar et al., 2009) Besides this, PIC (polymorphism information content) described by (Botstein et al., 1980) and Resolving Power (Rp) (Prevost and Wilkinson, 1999) were also calculated (Table 2). The 0-1 matrix data of SSR analysis was subjected to calculate pairwise genetic similarity using Jaccard's coefficient (Jaccard, 1908). The similarity matrix thus obtained was subjected to prepare dendrogram (Figure 1) by unweighted pair group method of arithmetic averages (UPGMA) with the help of XLSTAT software version (Addinsoft, 2007). 


\section{Results and Discussion}

\section{Polymorphism of SSR markers}

Among 19 SSR primers screened for the study and only 10 primers $(52.63 \%)$ primers could amplify successfully. In the present study showed low level percent of amplification rate is in agreement with (Schafleitner et al., 2013) where more than 95\% SSR amplified reliably and used diversity analysis of a germplasm panel comprising 65 accessions. Another study showed 18 primers amplified the germplasm among the selected 25 primers where 725 SSR successfully amplified (Fougat et al., 2015). A total of 24 bands generated and all bands were observed as polymorphic by using ten SSR primers thus obtained $100 \%$ polymorphism. The size of bands scored in all the 69 genotypes were in the range of 100 to 1200 bp (Table 2). The number of amplified bands generated by individual SSR primer ranged from 1 (AVRDC OKRA-70, AVRDC OKRA-78, AVRDC OKRA-86 and AVRDC OKRA-28) to 8 (AVRDC OKRA-64) with an average of 2.4 bands per primer (Figure 2-5). The average bands per primer was slightly lower than studied with other workers (Schafleitner et al., 2013; Fougat et al., 2015; Sawadogo et al., 2009) with SSR markers, (Gulsen et al., 2007) with SRAP markers (Akash et al., 2013) with AFLP markers and (Prakash et al., 2011) with RAPD markers. Polymorphic information content varied from 0.49-0.99 with an average 0.72. The highest PIC value related to AVRDC OKRA-64, which makes it the most informative primer combination and producing eight polymorphic bands. Fougat et al., (2015) reported the similar results though slightly lower PIC values (0.00 to 0.89 ) from 24 okra accessions. Both studies found a liner relationship between the ability to distinguish between genotypes and values of PIC. Resolving power ( $R p)$ as a measure of the discriminatory power of molecular marker and resolving power varies from 0.145 to 3.97 with an average 1.84. In the present study, the percent of polymorphic bands was $100 \%$ which was comparable to other SSR-based studies conducted on okra germplasm (Sawadogo et al., 2009 and Fougat et al., 2015) who has observed less polymorphism as then present study.

\section{Genetic diversity analysis}

All the 24 bands, generated by nine SSR primes were used for genetic diversity studies. Moderate level genetic diversity was observed in the germplasm as indicated by the range of Jaccard's similarity co-efficient, 0.50 to 0.958 with an average 0.772 . Hence, it is clear from the results that some of the okra germplasm used in the present study were the members of more restricted germplasm pool although cultivars were collected from the two different geographic locations. However, a number of germplasm found similar in the molecular studies showed narrow genetic base. Combinations generated by okra genotypes, the maximum similarity (0.958) were found between the 282-10-1 and 167 and lowest similarity (0.50) were observed 454-10-1. High similarity among the accessions studied was expected because okra has highly self-pollinated species (Hamon and Koechlin, 1991) and similar results were also reported by Gulsen et al., (2007) and Sharma et al., (2015) who has also observed $100 \%$ similarity in cultivars among the grapefruit cultivars

\section{Relationship among the accession}

The UPGMA based on the clustering 69 okra genotypes were divided into three major groups (Fig. 3). Group I contained 13 cultivars, (681012, 282-10-1, 629-7-12-3, 223, 263, SKA-TR-RS-113, 37, IC-169302, EC-16936, 307-10-1, 151-101-2-3, 137-10-12 and 409) while, group II had only one genotype (212-10-1) which was found more 
diverse (Table 3). The group III contained 55 genotypes which were further subdivided in thirteen sub-groups (sub group I to XIII). The sub-group I contained three cultivars (1773, IC-28872, and 317-10-1), while, subgroup II comprised of seven genotypes (2A, 1875, KS442, 67-10-30, FB-10, 135-10-1 and 138-101). Subgroup III had only seven genotypes which includes, BO-2, C-1810, KS-446, 6844-1, 231-10-1, IC-11527, IC-306053.

Table.1 List of 69 Okra germplasm used in the study

\begin{tabular}{|c|c|c|c|c|c|}
\hline $\begin{array}{l}\text { S. } \\
\text { No. }\end{array}$ & \begin{tabular}{|l|} 
Name of \\
germplasm
\end{tabular} & Source & \begin{tabular}{|l} 
S. No. \\
\end{tabular} & \begin{tabular}{|l} 
Name of \\
germplasm
\end{tabular} & Source \\
\hline 1 & IC-28872 & IIVR Varanasi & 36 & 238 & - do- \\
\hline 2 & IC-306053 & -do- & 37 & $217-10-1$ & - do- \\
\hline 3 & 1773 & - do- & 38 & 446 & -do- \\
\hline 4 & 648-4-1 & -do- & 39 & 1668 & -do- \\
\hline 5 & $67-10-3$ & -do- & 40 & SK4-8R-RS-8S & -do- \\
\hline 6 & 5135 & -do- & 41 & 770 & -do- \\
\hline 7 & $21-10-1$ & - do- & 42 & 118 & -do- \\
\hline 8 & $282-10-1$ & -do- & 43 & 177 & -do- \\
\hline 9 & $317-10-1$ & - do- & 44 & SC-108 & -do- \\
\hline 10 & IC-11527 & -do- & 45 & $332-10-1$ & -do- \\
\hline 11 & $138-10-1$ & -do- & 46 & Parbhani-Kranthi & -do- \\
\hline 12 & 1999 & -do- & 47 & FB-10 & -do- \\
\hline 13 & $135-10-1$ & -do- & 48 & VRO-5 & -do- \\
\hline 14 & $155-1-1-2-3$ & - do- & 49 & C-1801 & -do- \\
\hline 15 & $68-10-12$ & - do- & 50 & BO-2 & -do- \\
\hline 16 & $629-7-12-3$ & -do- & 51 & VRO-3 & -do- \\
\hline 17 & SKX-QR-RS-10-7 & -do- & 52 & KS-310 & -do- \\
\hline 18 & $231-10-1$ & -do- & 53 & KS-442 & -do- \\
\hline 19 & 223 & -do- & 54 & C-11-HR-4 & -do- \\
\hline 20 & 1875 & -do- & 55 & KS-305-AB-3 & -do- \\
\hline 21 & $212-10-1$ & - do- & 56 & KS-446 & -do- \\
\hline 22 & $2 \mathrm{~A}$ & -do- & 57 & C-8901 & -do- \\
\hline 23 & 263 & -do- & 58 & KS-311 & -do- \\
\hline 24 & SKA-TR-RS-113 & -do- & 59 & KS-404 & -do- \\
\hline 25 & $454-10-1$ & -do- & 60 & Kashi-Mohini & IIHR Bangalore \\
\hline 26 & 37 & -do- & 61 & Kashi-Lalima & -do- \\
\hline 27 & IC-169302 & -do- & 62 & Kashi-Vibhuti & -do- \\
\hline 28 & EC-169367 & -do- & 63 & Kashi-Pragati & -do- \\
\hline 29 & $307-10-1$ & - do- & 64 & Varsha-Uphar & -do- \\
\hline 30 & 151-101-2-3 & -do- & 65 & Utkal-Gourav & -do- \\
\hline 31 & $137-10-12$ & -do- & 66 & $\mathrm{CO}-2$ & -do- \\
\hline 32 & 409 & -do- & 67 & Pusa-Sawani & -do- \\
\hline 33 & 167 & - do- & 68 & Arka-Anamika & -do- \\
\hline 34 & 326 & -do- & 69 & S-1 & -do- \\
\hline 35 & 108-10-12I & -do- & & & \\
\hline
\end{tabular}


Table.2 Characteristics of the amplification products obtained with 10 SSR primers used to analysis the Genetic diversity of okra accessions

\begin{tabular}{|c|c|c|c|c|c|c|c|c|}
\hline & Primer & Primer sequence & SSR Motive & $\begin{array}{l}\text { Observed Product } \\
\text { position (bp) }\end{array}$ & $\begin{array}{l}\text { Expected } \\
\text { Product size }\end{array}$ & PIC & $\mathbf{R P}$ & $\begin{array}{l}\text { No. of } \\
\text { alleles }\end{array}$ \\
\hline \multirow[t]{2}{*}{1} & \multirow{2}{*}{$\begin{array}{l}\text { AVRDC OKRA- } \\
21\end{array}$} & TCATGTCTTTCCACTCAACA & \multirow[b]{2}{*}{$(\mathrm{AGA}) 9$} & \multirow{2}{*}{$180-200$} & \multirow{2}{*}{194} & \multirow{2}{*}{0.58} & \multirow{2}{*}{2.57} & \multirow{2}{*}{2} \\
\hline & & CCAAACAAAATATGCCTCTC & & & & & & \\
\hline \multirow[t]{2}{*}{2} & \multirow{2}{*}{$\begin{array}{l}\text { AVRDC OKRA- } \\
39\end{array}$} & TGAGGTGATGATGTGAGAGA & \multirow[b]{2}{*}{$(\mathrm{AG}) 16$} & \multirow[b]{2}{*}{$600-900$} & \multirow[b]{2}{*}{115} & \multirow[b]{2}{*}{0.99} & \multirow[b]{2}{*}{0.14} & \multirow[b]{2}{*}{3} \\
\hline & & TTGTAGATGAGGTTTGAACG & & & & & & \\
\hline \multirow[t]{2}{*}{3} & \multirow{2}{*}{$\begin{array}{l}\text { AVRDC OKRA- } \\
52\end{array}$} & AACACATCCTCATCCTCATC & \multirow[b]{2}{*}{$(\mathrm{CAT}) 8-(\mathrm{TCA}) 9$} & \multirow[b]{2}{*}{$200-205$} & \multirow[b]{2}{*}{203} & \multirow[b]{2}{*}{0.73} & \multirow[b]{2}{*}{1.53} & \multirow[b]{2}{*}{2} \\
\hline & & ACCGGAAGCTATTTACATGA & & & & & & \\
\hline \multirow[t]{2}{*}{4} & \multirow{2}{*}{$\begin{array}{l}\text { AVRDC OKRA- } \\
57\end{array}$} & CGAGGAGACCATGGAAGAAG & \multirow{2}{*}{$(\mathrm{GAA}) 9-(\mathrm{GAG}) 7$} & \multirow{2}{*}{$200-350$} & \multirow{2}{*}{322} & \multirow{2}{*}{0.79} & \multirow{2}{*}{2.08} & \multirow{2}{*}{3} \\
\hline & & ATGAGGAGGACGAGCAAGAA & & & & & & \\
\hline \multirow[t]{2}{*}{5} & \multirow{2}{*}{$\begin{array}{l}\text { AVRDC OKRA- } \\
63\end{array}$} & GTGTTTGAAAGGGACTGTGT & & & & & & \\
\hline & & CTTCATCAAAACCATGCAG & $(\mathrm{TCT}) 12$ & $230-250$ & 241 & 0.49 & 2.84 & 2 \\
\hline 6 & AVRDC OKRA- & AAGGAGGAGAAAGAGAAGGA & & & & & & \\
\hline & 64 & ATTTACTTGAGCAGCAGCAG & $(\mathrm{TCT}) 22$ & $150-1200$ & 152 & 0.81 & 3.91 & 8 \\
\hline 7 & AVRDC OKRA- & GTAGCTGAACCCTTTGCTTA & & & & & & \\
\hline & 70 & CTATCATGGCGGATTCTTTA & (TC) 11 & 180 & 170 & 0.98 & 1.97 & 1 \\
\hline 8 & AVRDC OKRA- & CTCCGACAATTCAAGAAAAG & & & & & & \\
\hline & 78 & CACCCAATCAAGCTATGTTA & (TATCGT) 4 & 190 & 189 & 0.53 & 1.07 & 1 \\
\hline 9 & AVRDC OKRA- & ATGCAAACAAGCTAGTGGAT & & & & & & \\
\hline & & ATTCTCTTCAGGGTTTCCTC & $(\mathrm{AGC}) 8$ & $2 / 4$ & $2 / 4$ & 0.51 & 1.14 & 1 \\
\hline 10 & AVRDC OKRA- & CCTCTTCATCCATCTTTTCA & & & & & & \\
\hline & 28 & GGAAGATGCTGTGAAGGTAG & $($ ATT) 8 & 240 & 242 & 0.71 & 1.07 & 1 \\
\hline & Average & & & & & 0.72 & 1.84 & 2.4 \\
\hline
\end{tabular}


Fig.1 Dendogram sowing clustering of 69 genotypes constructed using UPGMA based on jaccard s simililarity coefficient obtained from SSR analysis

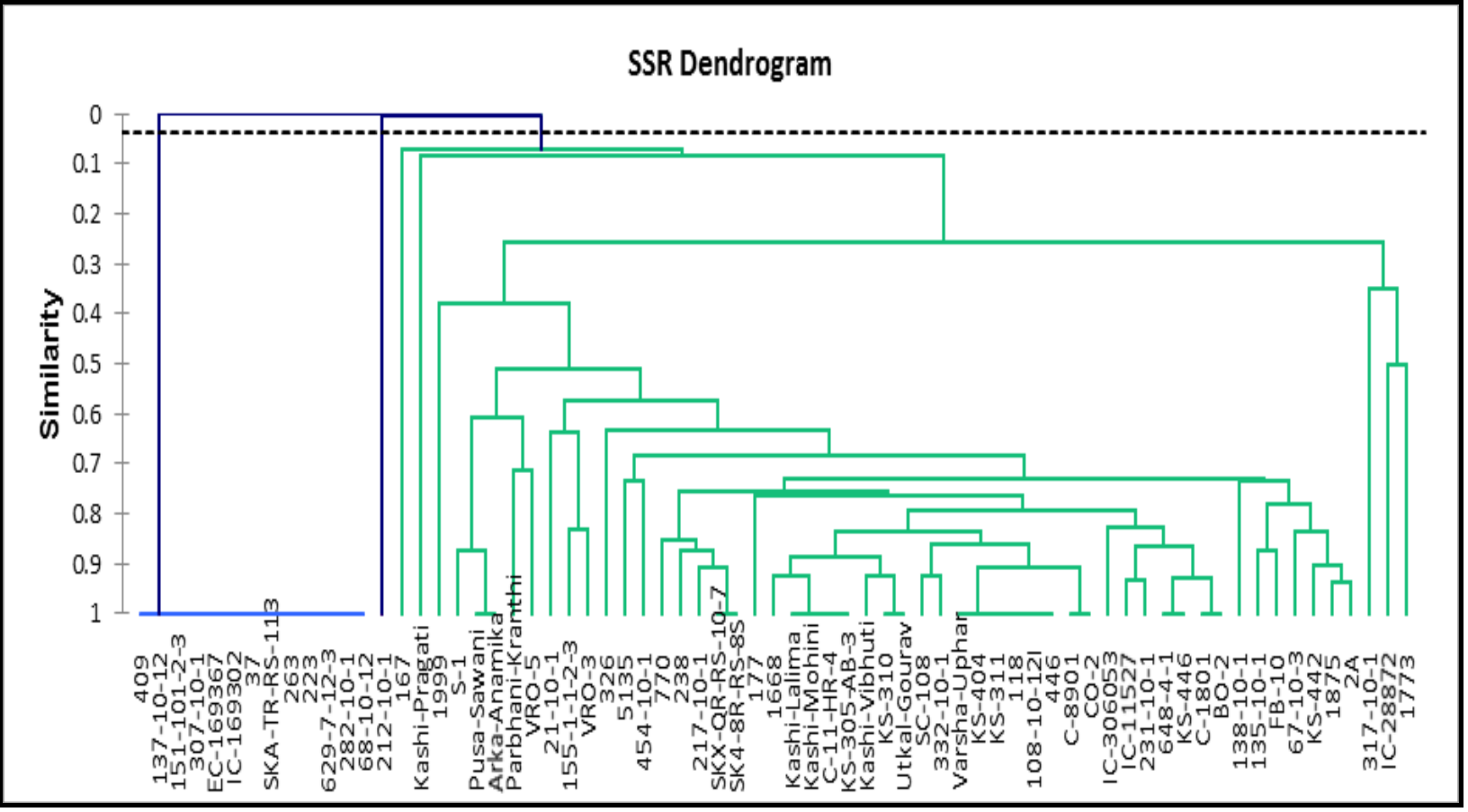

Fig.2 Representative Gel image depicting PCR amplifications using SSR primers AVRDC OKRA-64 (1-34) of okra represents marker 100bp ladder

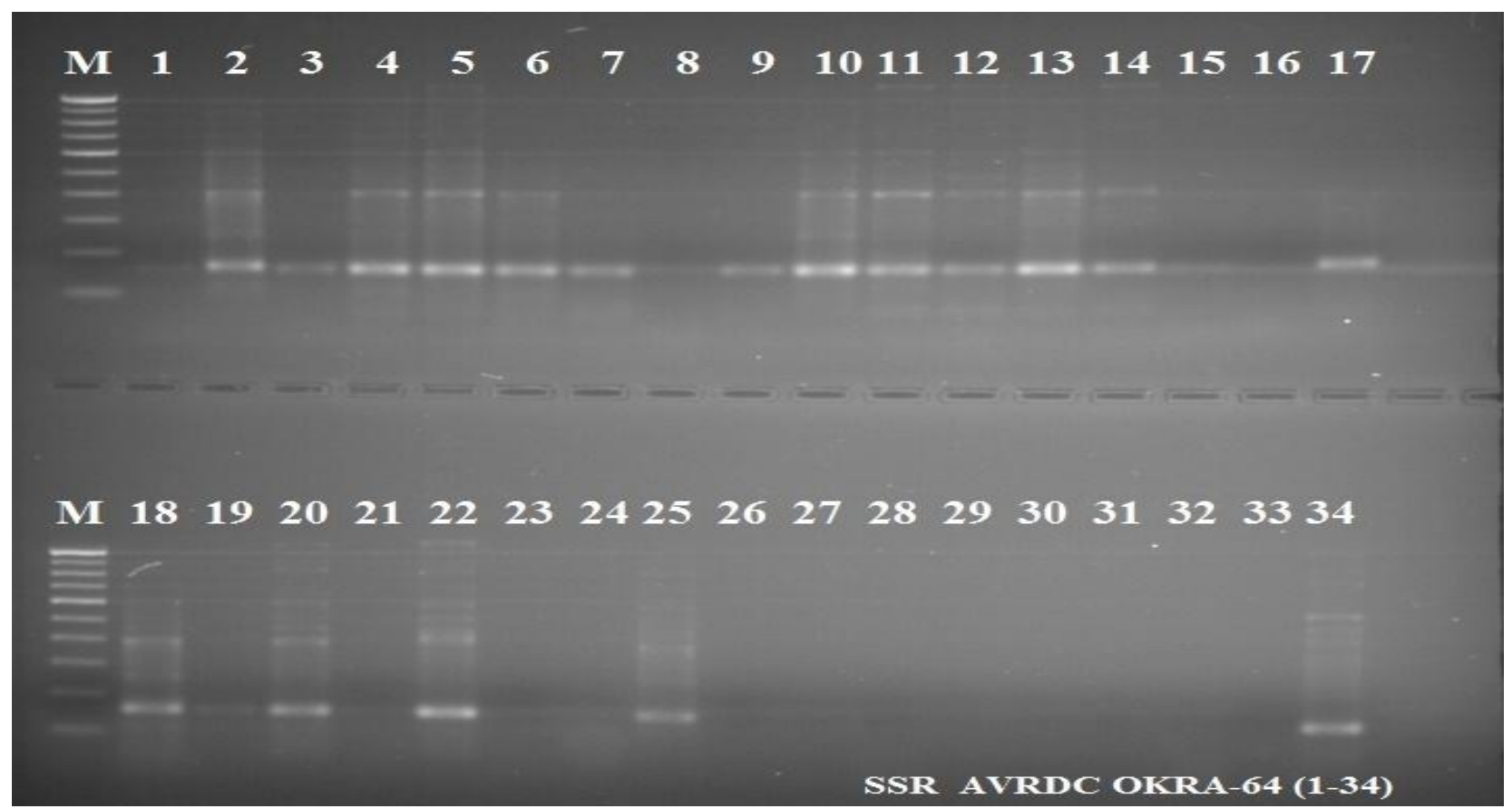


Fig.3 Representative Gel image depicting PCR amplifications using SSR primers AVRDC OKRA-64 (35-69) of okra represents marker 100bp ladder

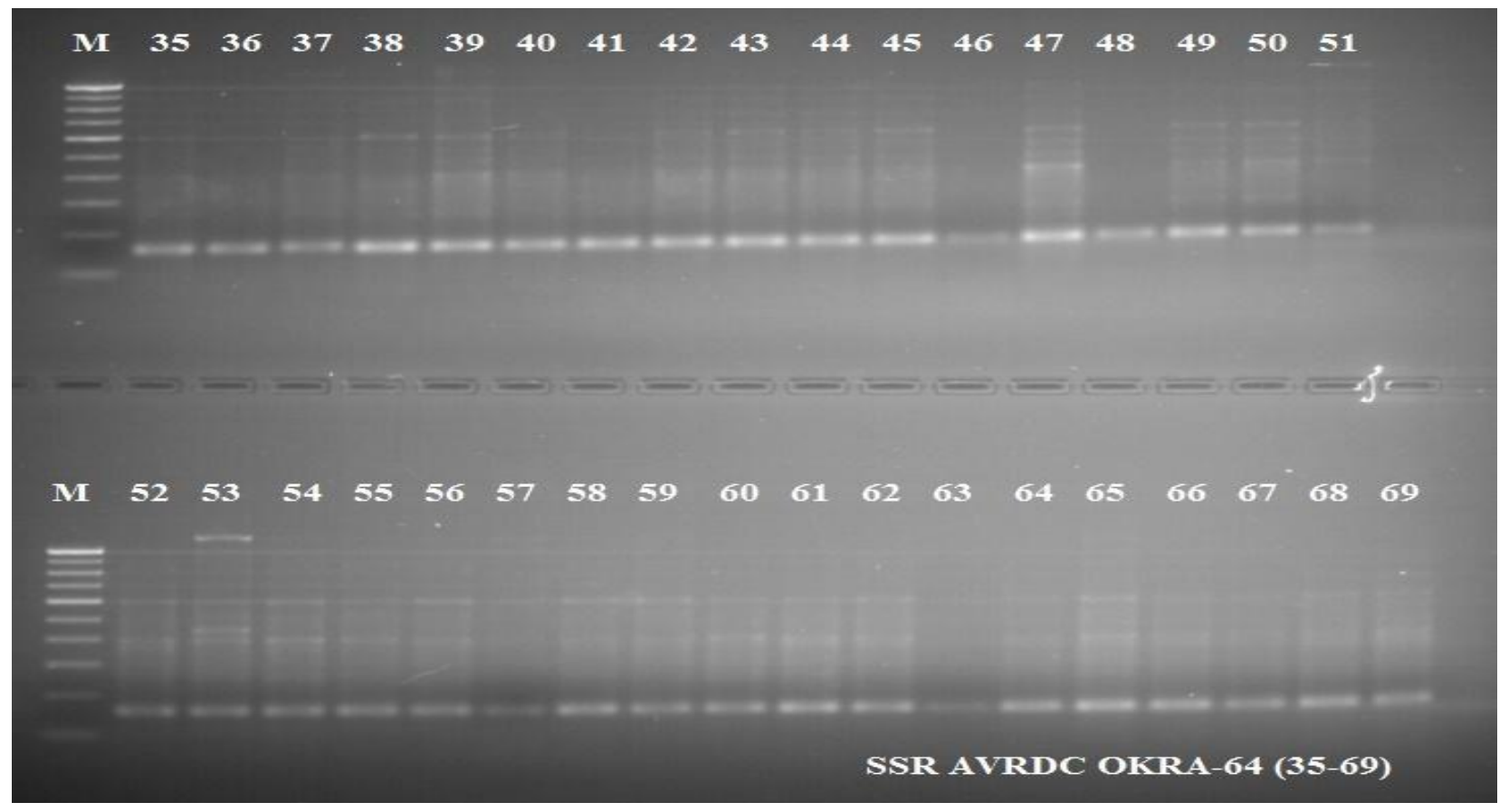

Fig.4 Representative Gel image depicting PCR amplifications using SSR primers AVRDC OKRA-86 (1-34) of okra represents marker 100bp ladder

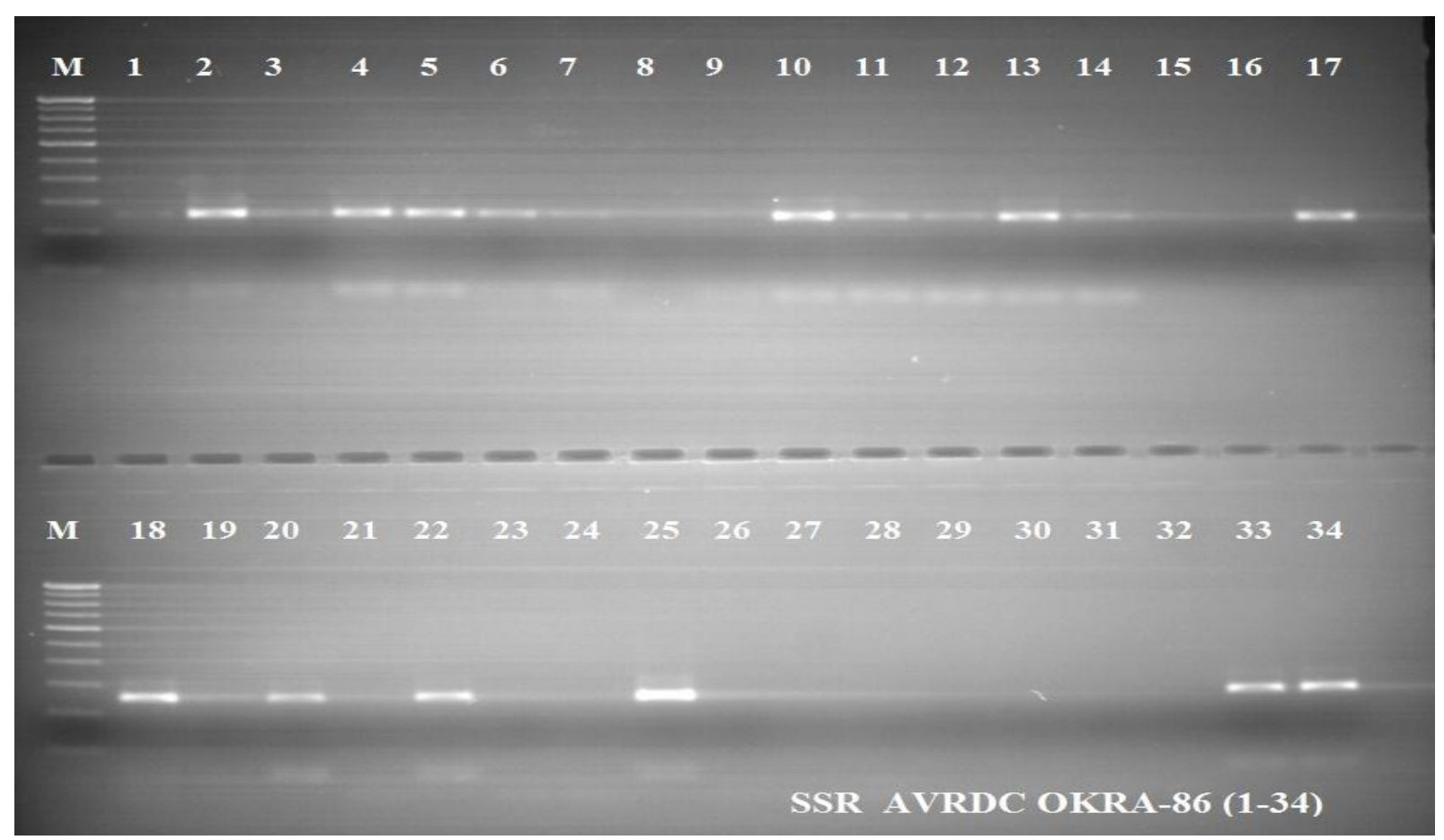


Fig.5 Representative Gel image depicting PCR amplifications using SSR primers AVRDC OKRA-86 (35-69) of okra represents marker 100bp ladder

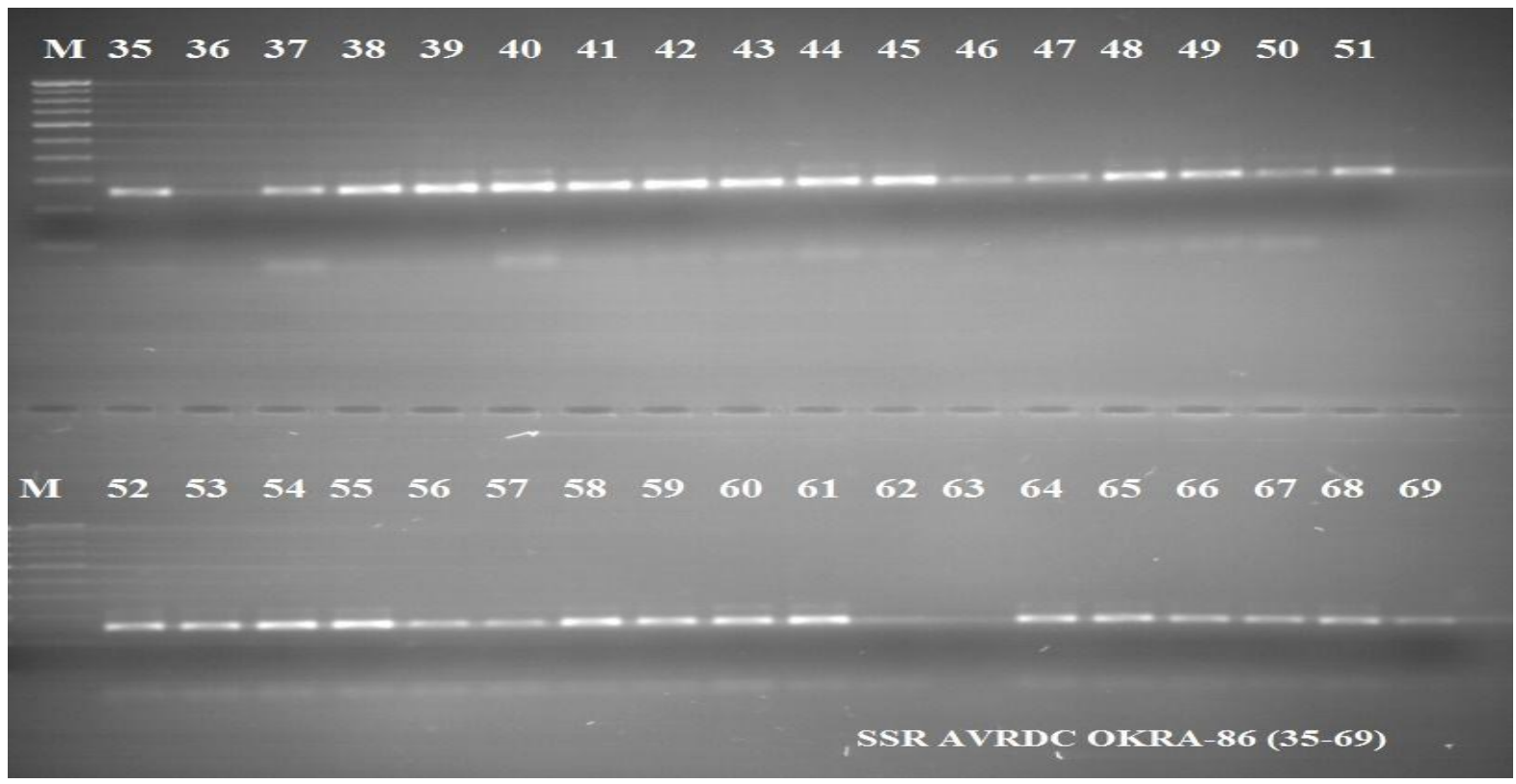

The sub group IV contained eighteen genotypes (CO-2, C-8901, 446, 108-10-121, 118, KS-311, KS-404, Varsa Uphar, 332-101, SC-108, Utkal Gourav, KS-310, Kashi Vibhuti, KS-305-AB-3, C-11-HR-4, Kashi Mohini, Kashi Lalima and 1668) while, sub group V, VIII, XI, XII and XIII had only one genotype (177, 326, 1999, Kashi Pragati and 167 respectively). Sub group VI contained five genotypes (SK 4-8R-RS-8S, SKX-QRRS-10-7, 217-10-1, 238 and 770) while, subgroup VII had two genotypes (454-10-1 and 5135). Subgroup IX had three genotypes (VRO-3, 155-1-1-2-3 and 21-10-1) while, subgroup $\mathrm{X}$ having five genotypes (VRO-5, Parbhani Kranti, Arka Anamika, Pusa Sawani and S-1). Among these, 2 genotypes were found together in dendogram (Figure 1) (Pusa Sawni and Arka Anamika). It is also notable that these genotypes are released variety and their parents are different. Pusa Sawani obtained from the cross between (IC $1542 \mathrm{x}$ and Pusa Makhmali) and Arka Anamika is a cross between (IIHR20-31) x A. manihot spp. Tetraphyllus). However, both cultivars have been observed susceptible to Yellow Vein
Mosaic Virus (YVMV). In the present analysis, we were found four more diverse genotype including 212-10-1, 167, Kashi Pragati and 1999 which can be used as diverse parents in breeding programme.

The distribution of genotypes bearing to same geographical regions was found in different clusters, indicating no correlation between molecular grouping and their geographical region. Similar findings have also been observed by Prakash et al., (2011) in okra. This might have been due to free exchange of germplasm that has taken place between different places. However, molecular grouping made had shown some resemblance with genotypes which had been collected from different geographical regions showed in same cluster. It might be due that some germplasm has adapted the local climate, various lands of crop field's long-time domestification and selection after introduction. In addition, physiological effects such as temperature and light differ with an altitude have to be considered although latitude is not changed. This result was 
consistent with data in a study by Ma et al., (2009) and Chen et al., (2013) in garlic.

Implications for conservation of
germplasm

The characterization, conservation and exploitation of crop plant germplasm maintained in gene banks propound a number of challenges to the researchers dedicated to the investigation of plant genetic resources. The Food and Agriculture Organization (FAO) supported the International Treaty on Plant Genetic Resources (ITPGR) and UN supported the Convention on Biological Diversity (CBD) which is the international agreements that recognize the important role of genetic diversity conservation. Such treaty still plays in current and future food production as one of the major role. Land races or traditional varieties have been found to have higher stability (adaptation over time) in low-input agriculture under marginal environments, thus, their cultivation may contribute farm level resilience in face of food production shocks Ceccarelli and Grando, (2002). In the present study, screening with the 10 SSR primers revealed the duplicacy of grmplasm. So among 69 okra accessions, a total of 31 accessions could be considered as duplicate of the plant materials (Figure 1). The present results are close conformity the earlier results by Almajali et al., (2012) who has observed the duplicacy in the fig germplasm by using ISSR markers. Sharma et al., (2015) also observed the duplicacy among the grapefruit germplasm by using SSR markers. It has been observed from the present study, SSR markers can provide the basic information necessary to help for conservation of germplasm from different genetic background rather than duplicates from same accession. So different accessions could have the same landraces and it might have been due to free exchange of germplasm that has taken place between different places.
In the present study, Information on genetic diversity will be essential for providing further insight into the breeding programme and genetic relationship of crop germplasm and SSR provided good insists of genetic diversity available in okra germplasm. The results obtained in our study showed that the ISSR markers were successfully used for okra. However, it's also suggested that SSR analysis less time consuming, less expensive more reliable, reproducible and generate more reliable, reproducible and generate more accurate results. Due to unique SSR fingerprints, the present investigation has provided a useful insight into the extent for determination of cultivar purity and efficient use of genetic resources and their collection.

\section{References}

Addinsoft, (2007). XLSTAT 2007, data analysis and statistics with Microsoft excel, Paris, france MacOS ed.

Akash, M.W., Shiyab, S.M. and Saleh, M.I. (2013). Yield and AFLP analyses of inter-landrace variability in okra (Abelmoschus esculentus L.). Life Science J., 10: 2771-2779

Almajali, D., Abdel-Ghani, A.H. and Migdadi, H. (2012). Evaluation of genetic diversity among Jordanian fig germplasm accessions by morphological traits and ISSR Markers. Sci. Hortic., 147: 8-19.

Anand, L.J., Murty, B.R. (1968). Genetic divergence and hybrid performance in linseed. Indian J. Genet., 28:178-185

Botstein, D., White, R.L., Skolnick, M. and Davis, R.W. (1980). Construction of a genetic linkage map in man using restriction fragment length polymorphisms. Am. J. Hum. Genet, 32: 314-331.

Burkil, H.M. (1997). The useful plant of West African 2nd edition. Vol. 4, Families 
M-R, Royal Botanic Garden.Kew United Kingdom pp. 969

Calisir, S., Ozcan, M., Haciseferogullari, H. and Yildiz, M.U. (2005). A study on some physico-chemical properties of Turkey okra (Hibiscus esculentus L.) seeds. J. Food Eng., 68: 73-78.

Ceccarelli, S. and Grando, S. (2002). "Plant breeding with farmers requires treating the assumptions of conventional plant breeding: lesson from the ICCRDA Barely Program," in Farmers,Scientists and Plant Breeding Integrating Knowledge and Practice,D. A. Cleveland and D. Soleri, Eds., CABI International, New York, NY, USA.

Chen, S., Zhon, J., Chem, Q., Chang, Y., Du, J. and Meng, H. (2013). Analysis the genetic diversity of garlic (Allum sativum L.) germplasm by SRAP. Bioch. Syst. and Ecol., 50: 139-146.

Doyle, J.J. and Doyle, J.L. (1990) Isolation of plant DNA from fresh tissue. Focus 12: $13-15$.

Ford, C.E. (1938). A contribution to a cytogenetically survey of the Malvaceae. Genetica 20: 431-452.

Fougat, R.S., Purohit, A., Kumar, S., Parekh, M.J. and Kumar, M. (2015). SSR based genetic diversity in Abelmoschus species. Indian J of Agric Sci 85 (9): 1223-1228.

Gul, M.Z., Bhakshu, L.M., Ahmad, F., Kondapi, A.K., Qureshi, I.A. and Ghazi, I.A. (2011). Evaluation of Abelmoschus moschatus extracts for antioxidant, free radical scavenging, antimicrobial and antiproliferative activities using in vitro assays. BMC Complement Altern Med 11: 64-75

Gulsen, O., Karagul, S.and Abak, K. (2007). Diversity and relationships among Turkish okra germplasm by SRAP and phenotypic marker polymorphism. Biologia Bratislava 62: 41-50.
Hamon, S. and Koechlin, J. (1991). The reproductive biology of okra. 2. Selffertilization kinetics in the cultivated okra (Abelmoschus esculentus), and consequences for breeding. Euphytica 53: 49-55.

Jaccard, P (1908). Nouvelles recherches sur la distribution florale. Bull Soc Vaud Nat 44: 223-270.

Kumar, S., Dagnoko, S., Haougui, A., Ratnadass, A., Pasternak, D. and Kouame, C. (2010). Okra (Abelmoschus spp.) in West and Central Africa: potential and progress on its improvement. African J Agri Res 5: 3590-3598

Kumar, V., Sharma, S., Sharma, A.K., Sharma, S. and Bhat, K.V. (2009). Comparative analysis of diversity based on morpho-agronomic traits and microsatellite markers in common bean. Euphytica 170: 249-262.

Ma, K.H., Kwag, J.G., Zhao, W., Dixit, A., Lee, G.A., Kim, H.H., Chung, I. M., Kim, N. S., Lee, J. S., Ji, J. J., Kim, T. S. and Park, Y. J. (2009). Isolation and characteristics of eight noval polymorphic microsatellite loci from the genome of garlic (Allium sativume L.). Sci. Hortic. 122 (3): 355-361.

Prakash, K., Pitchaimuthu, M. and Ravishankar, K.V. (2011). Assessment of genetic relatedness among okra genotypes (Abelmoschus esculentus (L.) Moench] using RAPD markers. Electronic J of Plant Breed 2(1): 80-86

Prevost, A. and Wilkinson, M. (1999). A new system of comparing PCR primers applied to ISSR fingerngerprinting of potato cultivars. Theor Appl Genet 98, 107-112.

Sawadogo, M., Jeremy, T., Ouedraogo, B.D., Ouedraogo, M., Gowda, B.S., Botanga, C. and Timko, M.P. (2009). The use of cross species SSR primers to study genetic diversity of okra from Burkina 
Faso. African $\mathbf{J}$ of Biotechnology 8 (11): 2476-2482.

Schafleitner, R., Kumar, S., Lin, C., Hegde, S.G. and Ebert, A. (2013). The okra (Abelmoschus esculentus) transcriptome as a source for gene sequence information and molecular markers for diversity analysis. Gene 17: 27-36

Sharma, N., Dubey, A.K., Srivastav, M., Singh, B.P. and Singh AK, and Singh, N.K. (2015). Assessment of genetic diversity in grapefruit (Citrus paradisi Macf) cultivars using physico-chemical parameters and microsatellite markers. Australian J of Crop Sci 9(1): 62-68.

Siemonsma, J.S. (1982). West African okramorphological and cytogenetical indicators for the existence of a natural amphidiploid of Abelmoschus esculentus (L.) and A. manihot (L.) Mediks. Euphytica 31: 241-225.

Varmudy, V. (2011). Marketing Survey needed to boost okra exports. Department of economic Vive Kananda College, Puttur Karnataka.

\section{How to cite this article:}

Mukesh Kumar, V. Rakesh Sharma, Navneet Kumar, Ujjawal Sirohi, R.K. Naresh and Veena Chaudhary. 2017. Screening of Microsatellite Markers for Genetic Diversity Assessment and Conservation of Germplasm in Okra (Abelmoschus esculentus L. Moench). Int.J.Curr.Microbiol.App.Sci. 6(6): 509-520. doi: https://doi.org/10.20546/ijcmas.2017.606.060 